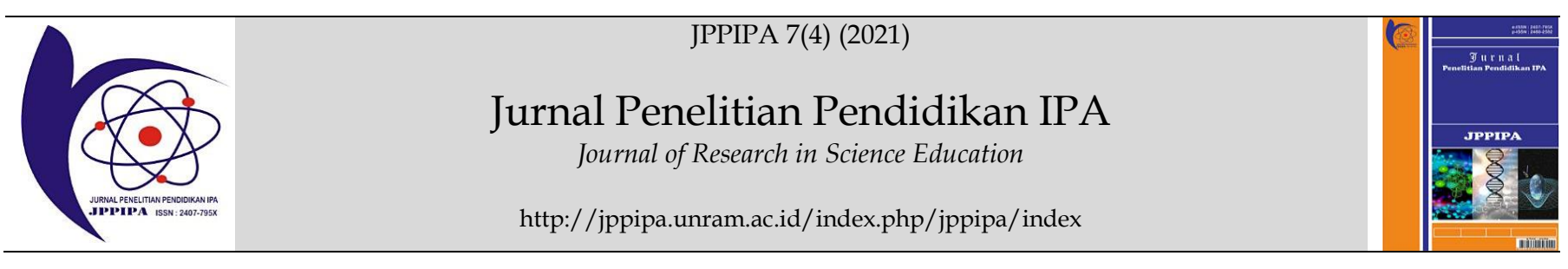

\title{
Use of Tracker Application on Kinetic Orbital Art (KOA) and Magic Gyroscope as Physics Learning Media
}

\author{
Desi Ramadhanti ${ }^{*}$, Heru Kuswanto1 ${ }^{1}$, Hestiana$^{1}$, Sabila Yasaroh¹, Aisha Azalia1 \\ ${ }^{1}$ Master Program of Science Education, FMIPA, Yogyakarta State University, Yogyakarta, Indonesia.
}

DOI: $\underline{10.29303 / \text { ippipa.v7i4.790 }}$

\section{Article Info}

Received : June $13^{\text {th }}, 2021$

Revised : August 26th 2021

Accepted: October 2nd, 2021

\begin{abstract}
This article aims to explain the use of tracker applications on Kinetic Orbital Art (KOA) and magic gyroscope in physics learning. This study uses descriptive analysis methods. The accelerated value of earth's gravity in the kinetic circular motion of orbital art and magic gyroscopes aided analysis with tracker applications and Microsoft Excel programs. The results will be compared to get a graph of position relationships with time. From research conducted on the motion of KOA and magic gyroscope assisted tracker application obtained acceleration value is $9.44 \mathrm{~m} / \mathrm{s}^{2}$ and $9.56 \mathrm{~m} / \mathrm{s}^{2}$. The graph obtained from both objects is not referred to as parabolic motion on the KOA chart resembles a parabolic motion, while the motion of the magic gyroscope is referred to as circular motion. Thus, the use of tracker application on KOA and magic gyroscope can be recommended as a learning medium of Physics in schools.
\end{abstract}

Keywords: Tracker app; KOA; magic gyroscope.

Citation: Ramadhanti, D., Kuswanto, H., Hestiana, H., Yasaroh, S., \& Azalia, A. (2021). Use Of Tracker Application On Kinetic Orbital Art (KOA) And Magic Gyroscope As Physics Learning Media. Jurnal Penelitian Pendidikan IPA, 7(4), 562-567. doi:https://doi.org/10.29303/jppipa.v7i4.790

\section{Introduction}

Physics is one of the learning subjects that develops from observing natural phenomena and interactions in the form of concepts, facts, principles, and laws (Asih, 2017; Amaliah et al., 2020). Therefore, physics learning in schools should emphasize the process of extracting concepts to provide attractiveness for students (Amaliah et al., 2020). In fact, physics learning in the classroom emphasizes more on formulas and theories than the handbook used. As a result, the basic ability of physics decreased drastically (Pinxten et al., 2017), understanding of concepts in low-category physics learning so that learners experience misconceptions in accepting the concept of physics taught (Sari et al., 2018). This can be seen from the number of students who mistakenly explain the concept of kinematics and the low average score of students during the exam (Taqwa \& Pilendia, 2018). Students tend to experience misconceptions of kinematics concepts in circular motion and parabolic motion (Tarisalia et al., 2020). Misconceptions of learners on the concept of circular motion are about the characteristics of circular motion and the magnitudes that affect circular motion (Annisa et al., 2019; Nisa et al., 2019). While the misconception of learners on parabolic motion is that learners tend to find it difficult to understand why the speed on the y-axis at the top of a projectile (parabola) is zero, although the acceleration is not zero (Kamaluddin \& Fihrin, 2016).

Related to that, physics learning activities will be more meaningful and interesting if done with experimental activities (Anissofira et al., 2017). Experimental activities can help learners understand the basic concepts of physics in real-time (Chiriacescu, 2020). The use of technology in learning is an effort to make it easier for learners to learn (Semerci \& Aydin, 2018), and facilitate the way educators interact and communicate with learners both in the classroom and outside the classroom (Tekege, 2017). The use of media in learning can arouse learning desires and interests, awaken learners' learning motivations, and help make teaching and learning activities more exciting and interactive (Tafonao, 2018; Chasanah et al., 2019). The

\footnotetext{
*Email: desiramadhanti.2020@student.uny.ac.id
} 
presence of learning media can help learners who have difficulty delivering abstract, theoretical, and available material can be resolved with the help of teaching media (Yanto, 2019). Thus, educators need media that can help obtain more accurate data when conducting experiments (Subali et al., 2021).

One learning medium that helps learners understand the concept of kinematics to experiment is the tracker (Subali et al., 2021; Hockicko, 2020). Tracker is supported with high digital resources in the form of the availability of tools that make it easier to present motion data from an experiment in the form of video and connect a video ready to be analyzed (Asrizal et al., 2018). Tracker displays accurate and representative physics symptoms in data and graph form (Sartika et al., 2019). Using the tracker application to experiment with the parameters of the concept of kinematics will be more accurate (Prima et al., 2016). The process of analyzing data is done in an uncomplicated way because it can get the results of the intended magnitude representation directly (Khairunnisa, 2019).

The use of tracker application is done by video analysis method on certain objects (Hockiko, 2020), two of which are Kinetic Orbital Art (KOA) and magic gyroscope. KOA is a table display that aims as decoration and education. Koa's working system is similar to the orbit of the Milky Way, consisting of various planets that circle the sun as the center of the galaxy and move in three dimensions, like an orbit on a planet that does not only rotate one way. KOA has the principle of "kinetic sculptures," which is a combination of physics and art that allows the object to move (Zhang et al., 2020). At the same time, the magic gyroscope is a gasing that, if rotated on top of the container, will not stop spinning. The magic gyroscope can be used as a prop in learning, one of which is the perpetual motion that can be used as a very interesting demonstration of science in front of the class. The advantage of the magic gyroscope is that the gasing is able to continue spinning for a long time. This is due to the magnetic force that provides energy for the gasing to continue rotating. The magnetic field is generated from the copper coil that is flowed by the battery's electric current. Thus, KOA and magic gyroscope can support physics learning.

Based on the above exposure tracker application can be used as a learning medium physics on the concept of kinematics. This article aims to explain the use of tracker applications on KOA and magic gyroscope in physics learning.

\section{Method}

The study used a direct experimental approach using trackers on KOA and magic gyroscopes. The measurement results with the tracker application are a comparison of the value of earth's gravitational acceleration in KOA and magic gyroscope assisted tracker application and graphs of positional relationship to time.

The experimental procedure is as follows, 1) Put KOA on a plain background, 2) Play and record the motion of KOA with the mobile phone camera, 3) Next use a tracker to analyze the data, 4) Repeat steps 1 to 3 using a magic gyroscope.

Analysis using tracker application is first to insert the video that has been recorded with the import menu, then the fan motion video in the frameset that is the initial and final frame that will be analyzed with the tracker. Next calibrated the stick by clicking the track menu >> new >> calibration tools >>calibration stick. Lastly, determine the mass point of the object being analyzed. The analysis method uses descriptive analysis, which will be compared to the value of earth's gravitational acceleration in kinetic orbital art circular motion and magic gyroscope assisted tracker application with Microsoft Excel program to obtain a graph of positional relationship to time.

\section{Result and Discussion}

Kinematics discusses the motion of objects regardless of the cause of the object moving (Nisma, 2018). The magnitudes in kinematics include trajectory, speed, acceleration, and time.

Tracking apps using video analysis help learners improve intellectual abilities in the form of comprehension concepts. Learners are easier to connect measurement results using trackers with theory and show the relationship between acquired graphs and interpreting specific motion graphs (Hockicko et al., 2016; Ramadhanti et al., 2021). The appearance of KOA motion and magic gyroscope using the tracker application is shown in Figures 1 and 2.

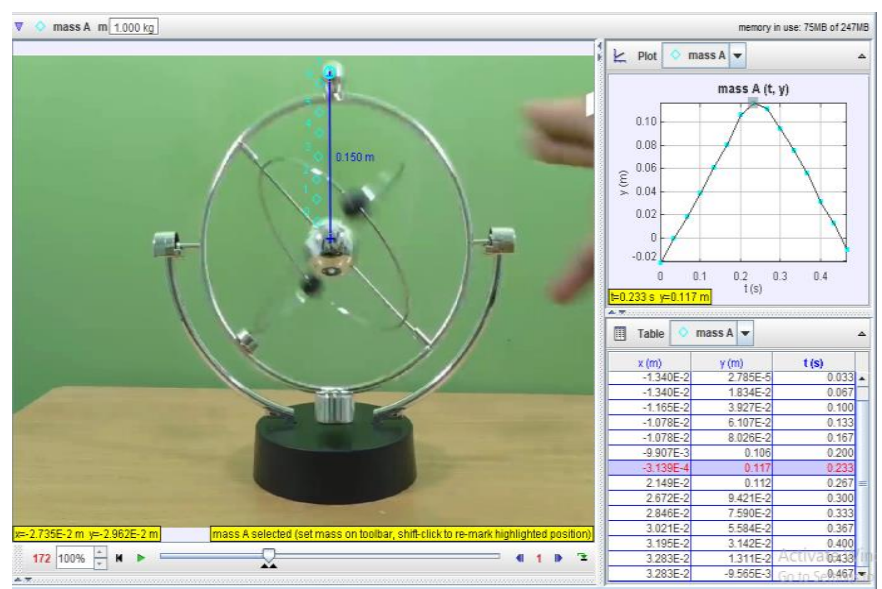

Figure 1. KOA Motion Display in Tracker App 
Motion magic gyroscope inputted with tracker application shown in Figure 2 below.

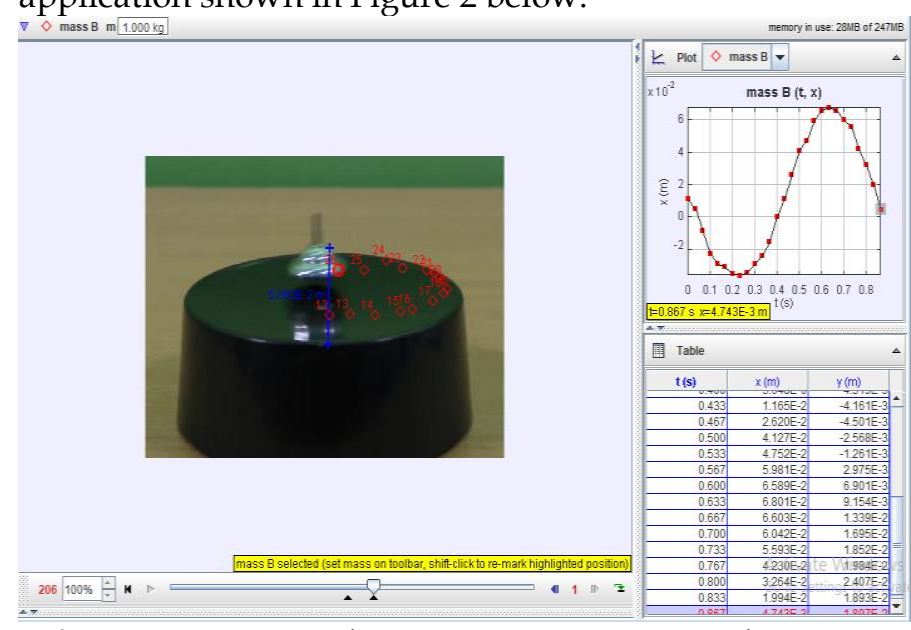

Figure 2. Motion Display Magic Gyroscope in Tracker App

The data analysis results using tracker application on KOA and magic gyroscope are shown in Table 1.

Table 1.

Table 1. Data Analysis Results Using Tracker Application on KOA and magic gyroscope

\begin{tabular}{lll}
\hline No & $\mathbf{t}(\mathbf{s})$ & $\mathbf{y}(\mathbf{m})$ \\
\hline 1 & 0 & $-0.21 \times 10^{-1}$ \\
2 & $0.33 \times 10^{-1}$ & $0.03 \times 10^{-1}$ \\
3 & $0.67 \times 10^{-1}$ & $0.18 \times 10^{-1}$ \\
4 & $1.00 \times 10^{-1}$ & $0.39 \times 10^{-1}$ \\
5 & $1.33 \times 10^{-1}$ & $0.61 \times 10^{-1}$ \\
6 & $1.67 \times 10^{-1}$ & $0.80 \times 10^{-1}$ \\
7 & $2.00 \times 10^{-1}$ & $1.06 \times 10^{-1}$ \\
8 & $2.33 \times 10^{-1}$ & $1.17 \times 10^{-1}$ \\
9 & $2.67 \times 10^{-1}$ & $1.12 \times 10^{-1}$ \\
10 & $3.00 \times 10^{-1}$ & $0.94 \times 10^{-1}$ \\
11 & $3.33 \times 10^{-1}$ & $0.76 \times 10^{-1}$ \\
12 & $3.67 \times 10^{-1}$ & $0.56 \times 10^{-1}$ \\
13 & $4.00 \times 10^{-1}$ & $0.31 \times 10^{-1}$ \\
14 & $4.33 \times 10^{-1}$ & $0.13 \times 10^{-1}$ \\
15 & $4.67 \times 10^{-1}$ & $-0.09 \times 10^{-1}$ \\
16 & 0 & $0.22 \times 10^{-1}$ \\
17 & $0.33 \times 10^{-1}$ & $0.23 \times 10^{-1}$ \\
18 & $0.67 \times 10^{-1}$ & $0.24 \times 10^{-1}$ \\
19 & $1.00 \times 10^{-1}$ & $2.26 \times 10^{-1}$ \\
20 & $1.33 \times 10^{-1}$ & $0.22 \times 10^{-1}$ \\
21 & $1.67 \times 10^{-1}$ & $0.18 \times 10^{-1}$ \\
22 & $2.00 \times 10^{-1}$ & $0.15 \times 10^{-1}$ \\
23 & $2.33 \times 10^{-1}$ & $1.25 \times 10^{-1}$ \\
24 & $2.67 \times 10^{-1}$ & $0.08 \times 10^{-1}$ \\
25 & $3.00 \times 10^{-1}$ & $0.03 \times 10^{-1}$ \\
26 & $3.33 \times 10^{-1}$ & $0.01 \times 10^{-1}$ \\
27 & $3.67 \times 10^{-1}$ & $-0.02 \times 10^{-1}$ \\
28 & $4.00 \times 10^{-1}$ & $-0.04 \times 10^{-1}$ \\
29 & $4.33 \times 10^{-1}$ & $-0.04 \times 10^{-1}$ \\
30 & $4.67 \times 10^{-1}$ & $-0.04 \times 10^{-1}$ \\
31 & $5.00 \times 10^{-1}$ & $-0.02 \times 10^{-1}$ \\
32 & $5.33 \times 10^{-1}$ & $-0.01 \times 10^{-1}$ \\
33 & $5.67 \times 10^{-1}$ & $0.03 \times 10^{-1}$ \\
\hline & &
\end{tabular}

\begin{tabular}{lll}
\hline No & $\mathbf{t}(\mathbf{s})$ & $\mathbf{y}(\mathbf{m})$ \\
\hline 34 & $6.00 \times 10^{-1}$ & $0.07 \times 10^{-1}$ \\
35 & $6.33 \times 10^{-1}$ & $0.09 \times 10^{-1}$ \\
36 & $6.67 \times 10^{-1}$ & $0.13 \times 10^{-1}$ \\
37 & $7.00 \times 10^{-1}$ & $1.70 \times 10^{-1}$ \\
38 & $7.33 \times 10^{-1}$ & $1.85 \times 10^{-1}$ \\
39 & $7.67 \times 10^{-1}$ & $0.19 \times 10^{-1}$ \\
\hline
\end{tabular}

Comparison of gravitational acceleration value on KOA circular motion and magic gyroscope obtained from tracker application in Table 2.

Table 2. Comparison of gravity acceleration values in KOA and magic gyroscope

\begin{tabular}{|c|c|c|}
\hline No & $\mathrm{g}\left(\mathrm{m} / \mathrm{s}^{2}\right)$ & \\
\hline 1 & KOA & Magic Gyroscope \\
\hline 2 & 9.44 & 9.56 \\
\hline
\end{tabular}

From Table 2, it is obtained that the value of koa gravitational acceleration and magic gyroscope, respectively, is $9.44 \mathrm{~m} / \mathrm{s}^{2}$ and $9.56 \mathrm{~m} / \mathrm{s}^{2}$. Thus the value of the gravitational acceleration of $\mathrm{KOA}$ and magic gyroscope is close to the value of the acceleration of gravity on earth which ranges from $9.78 \mathrm{~m} / \mathrm{s}^{\wedge} 2$ to $9.83 \mathrm{~m} / \mathrm{s}^{2}$ (Ménoret et al., 2018). But the value of gravitational acceleration in several different places may not be exactly the same. The higher a place from sea level, the smaller the acceleration of gravity (Firdaus et al., 2019). Chusni (2017) performed the acceleration value in the Yogyakarta area with a single measurement method of $9,689 \pm 0.009 \mathrm{~m} / \mathrm{s}^{2}$. Thus, the value of magic gyroscope acceleration conducted in Yogyakarta is equivalent to research conducted by Chusni (2017) compared to the acceleration value in KOA.

The graph of position relationship to time $y=f(t)$ on KOA and magic gyroscope is shown in the picture below.

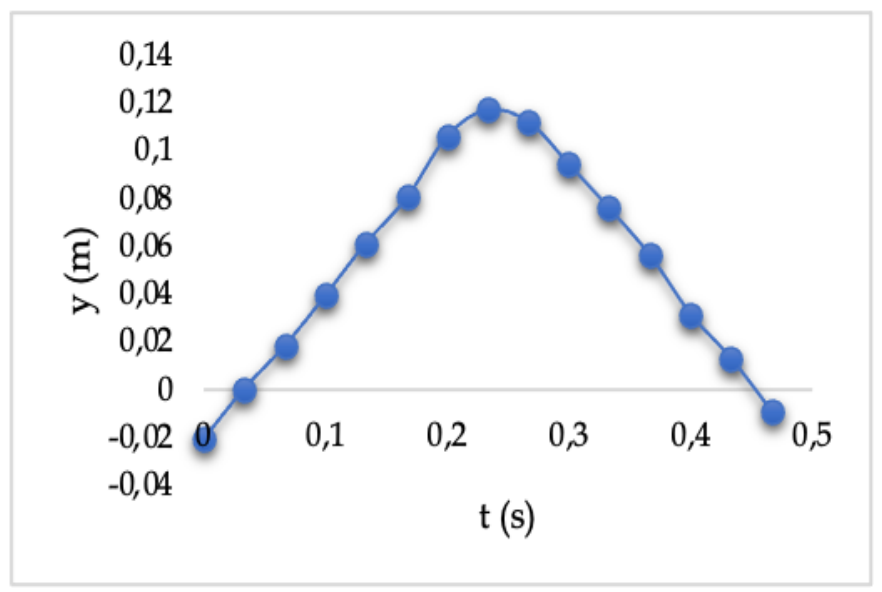

Figure 3. KOA Motion Graph Tracker App 


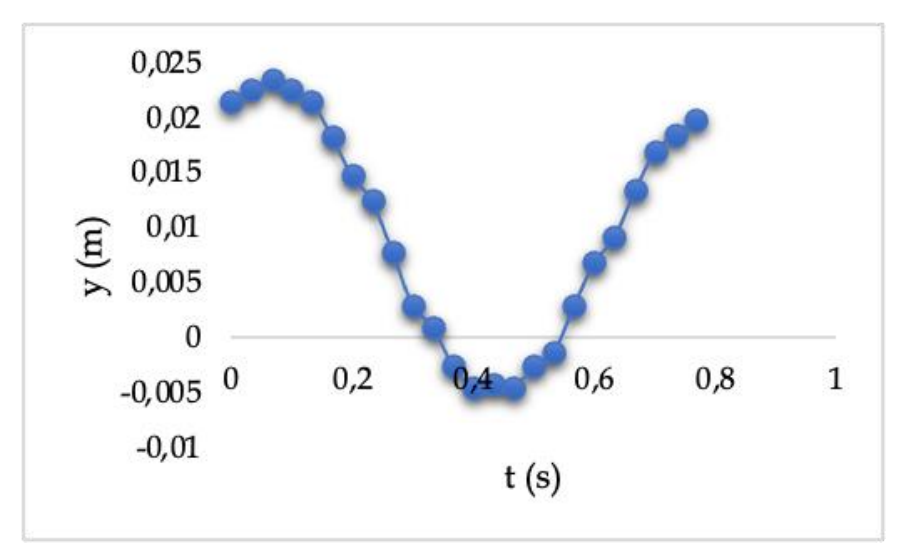

Figure 4. Magic Gyroscope Motion Graph Tracker App

Parabolic motion is a combination of motion between irregular straight motion analyzed from the breakdown of the x-axis (horizontal) and irregularly changed straight motion that can be analyzed from the decomposition of the $y$-axis (vertical). From Figures 3 and 4, it appears that the image is not intended to be a parabolic motion, and showing the position related to the time in KOA and magic gyroscope has a value that changes irregularly, and then the speed value changes in a regular manner. Figure 3 is almost similar to the motion of a parabola. Still, when viewed carefully, KOA's motion is not parabolic but rather forms like a mountain, and the speed value due to a change in position to time on the $y$ axis of the peak of a projectile (parabola) are not zero. However, the acceleration is not zero (Kamaluddin \& Fihrin, 2016). Thus, the use of tracker applications makes it easier for students to clearly understand the concept of kinematics by using data in the form of tables or graphs. This agrees with Ramadhanti et al.'s (2021) research, which states that the tracker application can be used as one of the alternative media used in learning. Figure 4 magic gyroscope motion has a perfect circular graph that is shown with the tracks on the chart that almost form a circle. Thus, the magic gyroscope is a regular circular motion because when moving circular has a fixed speed, the linear speed of objects that move in a circular irregularly always changes direction. This is because the centripetal acceleration that has a direction perpendicular to the trajectory of objects that move circularly and always has a direction towards the center of the circle (Tarisalia et al., 2020).

The use of tracker applications can help students conduct experiments independently by obtaining results in the form of a graph, table, and values (Subale et al., 2021). In addition, students quickly determine the acceleration value of the moving object. The use of trackers on KOA and magic gyroscopes can help train learners to understand the concept of kinematics, both parabolic motion and circular motion. In the end, the students will get results and conclusions. This is relevant to Trocaru's (2020) research, where the use of tracker applications by analyzing experimental videos motivates learners to learn and discover physical events in real life, and learners show this to be more active and responsive while studying.

\section{Conclusion}

From research conducted on the motion of KOA and magic gyroscope assisted tracker application obtained acceleration value is $9.44 \mathrm{~m} / \mathrm{s}^{2}$ and $9.56 \mathrm{~m} / \mathrm{s}^{2}$. The graph obtained from both objects is not referred to as parabolic motion on the KOA chart resembles a parabolic motion, while the motion of the magic gyroscope is referred to as circular motion. The magic gyroscope is referred to as ordinary circular motion because when circular movement has a fixed speed, the linear velocity of the object moving in an irregular circle always changes direction at all times caused by centripetal acceleration. Thus, the use of tracker application on KOA and magic gyroscope can be recommended as a learning medium of Physics in schools.

\section{References}

Amaliah, N. U., Saehana, S., \& Darmadi, I. W. (2020). Analisis Pemahaman Konsep Gerak pada Siswa yang Diajarkan dengan Media Video. Media Eksakta, 16(2), 84-88. Retrieved from https://jurnal.fkip.untad.ac.id/index.php/jme Larticle/view/738 [Indonesian]

Annisa, R., Astuti, B., \& Mindyarto, B. (2019). Tes Diagnostik Four Tier untuk identifikasi pemahaman dan miskonsepsi siswa pada materi gerak melingkar beraturan. Jurnal Pendidikan Fisika dan Keilmuan (JPFK), 5(1), 2532.

doi:http://dx.doi.org/10.25273/jpfk.v5i1.3546 [Indonesian]

Anissofira, A., Latief, F. D. E., Kholida, L., \& Sinaga, P. (2017). Newton's Cradle Experiment Using Video Tracking Analysis with Multiple Representation Approach. Journal of Physics: Conference Series, 895, 12107. https://doi.org/10.1088/17426596/895/1/012107.

Asih, D. (2017). Pengaruh Penggunaan Fasilitas Belajar di Lingkungan Alam Sekitar Terhadap Keterampilan Proses Sains. Formatif: Jurnal Ilmiah Pendidikan MIPA, 7(1). doi:http://dx.doi.org/10.30998/formatif.v7i1.1 331. [Indonesian] 
Asrizal, A., Yohandri, Y., \& Kamus, Z. (2018). Studi Hasil Pelatihan Analisis Video dan Tool Pemodelan Tracker pada Guru MGMP Fisika Kabupaten Agam. JURNAL EKSAKTA PENDIDIKAN (JEP), 2(1), 41-48. https://doi.org/10.24036/jep/vol2-iss1/84. [Indonesian]

Chasanah, R. N., Mujasam, Widyaningsih, S. W., \& Yusuf, I. (2019). Influence of The Use of Interactive Learning Media on Students' Higher Order Thinking Skills. Kasuari: Physics Education Journal, 2(1), 26-35. doi: https://doi.org/10.37891/kpej.v2i1.91

Chiriacescu, B., Chiriacescu, F. S., Miron, C., Berlic, C., \& Barna, V. (2020). Arduino and Tracker VideoDidactic Tools for Study of the Kater Pendulum Physical Experiment. Romanian Reports in Physics, 72(1), 1-14.

Chusni, M. M. (2017). Penentuan Besar Percepatan Gravitasi Bumi Menggunakan Ayunan Matematis Dengan Berbagai Metode Pengukuran. Scientiae Educatia: Jurnal Pendidikan Sains, 6(1), 47-53. doi:http://dx.doi.org/10.24235/sc.educatia.v6i 1.1346. [Indonesian]

Firdaus, T., Erwin, E., \& Rosmiati, R. (2019). Eksperimen Mandiri Siswa dalam Penentuan Percepatan Gravitasi Bumi pada Materi Gerak Jatuh Bebas. Titian Ilmu: Jurnal Ilmiah Multi Sciences, $\quad 11(1), \quad 31-36$. https://doi.org/10.30599/jti.v11i1.385.

[Indonesian]

Hockicko, P., \& Tarjányiová, G. (2016). Force concept inventory of first year students attending faculty of electrical engineering. 2016 ELEKTRO, 665-669. https://doi.org/10.1109/ELEKTRO.2016.75121 64.

Hockicko, P. (2020). Using Video Analysis Of Motions In Physics Teaching. The Online Journal of Science and Technology, 10(3), 126-134.

Kamaluddin, M. H., \& Fihrin, H. (2016). Analisis Pemahaman Konsep Gerak Lurus pada Siswa SMA Negeri di Kota Palu. Jurnal Pendidikan Fisika Tadulako (JPFT), 4(3), 1-3. Retrieved from: http://jurnal.untad.ac.id/jurnal/index.php/E PFT/article/view/6060 [Indonesian]

Khairunnisa. (2019). Pembelajaran Fisika Berbasis Tracker Dalam Penentuan Viskositas Air Menggunakan Metode Osilasi Teredam. Seminar Nasional Pendidikan MIPA dan Teknologi (SNPMT II), (pp. 108-115). Tasikmalaya. Retrieved from: https://journal.ikippgriptk.ac.id/index.php/s npmt2/article/view/1358 [Indonesian]
Ménoret, V., Vermeulen, P., Le Moigne, N., Bonvalot, S., Bouyer, P., Landragin, A., \& Desruelle, B. (2018). Gravity measurements below 10-9 g with a transportable absolute quantum gravimeter. Scientific Reports, 8(1), 0-11. https://doi.org/10.1038/s41598-018-30608-1.

Nisa, F., Yuliati, L., \& Mufti, N. (2019). Miskonsepsi Konsep Gerak Satu dan Dua Dimensi Siswa SMA. Jurnal Pendidikan: Teori, Penelitian, dan Pengembangan, 4, 1380-1385. doi: http://dx.doi.org/10.17977/jptpp.v4i10.12874 [Indonesian]

Nisma, E. B. J., Subiki, Astutik, S. (2018). Identifikasi Kinematika Di Jalur B-29 Lumajang Pada Konsep Fisika Melalui Rancangan LKS Fisika SMA. Seminar Nasional Pendidikan Fisika 2018, (pp. 32-39). Jakarta. [Indonesian]

Pinxten, M., Laet, D. T., Van Soon, C., Peeters, C., Kautz, C., Hockicko, P., \& Langie, G. (2017). Approaches to the Identification of STEM Key Competencies in European. Proceedings of the 45th SEFI Annual Conference, (pp. 389 -397). Portugal.

Prima, E. C., Mawaddah, M., Winarno, N., \& Sriwulan, W. (2016). Kinematics investigations of cylinders rolling down a ramp using tracker. Proceedings of International Seminar on Mathematics, Science, and Computer Science Education (MSCEIS) (pp. 1-6). Bandung: AIP Conference.

Ramadhanti, D., Kuswanto, H., Hestiana, Azalia, A. (2021). Penggunaan Analisis Video Gerak Kucing Melompat Berbantuan Aplikasi Tracker Sebagai Kegiatan Praktikum Mandiri Materi Gerak pada Peserta Didik SMP. Jurnal Pendidikan Sains Indonesia, 9(3), 459-470. doi: https://doi.org/10.24815/jpsi.v9i3.20547 [Indonesian]

Sari, A. L. R., Parno, Taufiq, A. (2018). Pemahaman Konsep dan Kesulitan Siswa SMA pada Materi Hukum Newton. Jurnal Pendidikan, 3(10), 13231330.

doi: http://dx.doi.org/10.17977/jptpp.v3i10.11663 [Indonesian]

Sartika, Y., Wahyudi, I., \& Abdurrahman, A. (2019). Using guided inquiry learning with tracker application to improve students' graph interpretation ability. Tadris: Jurnal Keguruan Dan Ilmu Tarbiyah, 4(1), 17-25. doi: https://doi.org/10.24042/tadris.v4i1.3060

Semerci, A., \& Aydin, M. K. (2018). Examining high school teachers attitudes towards ICT use in education. Internatinal Journal of Progressive Education, 14(2), 93-105. Retrieved from: https://eric.ed.gov/?id=EJ1177301 
Subali, B., Ulqia, N., Ellianawati, E., \& Siswanto4, S. (2021). Momentum Concept Learning Using Tracker as a Virtual Experiment Model: Looking at Students' Learning Independence. Jurnal Ilmiah Pendidikan Fisika Al-BiRuNi, 10(1), 19-28. doi:

https://doi.org/10.24042/jipfalbiruni.v10i1.70 $\underline{07}$

Tafonao, T. (2018). Peranan Media Pembelajaran dalam Meningkatkan Minat Belajar Mahasiswa. Jurnal Komunikasi Pendidikan, 2(2), 103-114. doi: https://doi.org/10.32585/jkp.v2i2.113 [Indonesian]

Taqwa, M. R., \& Pilendia, D. (2018). Kekeliruan Memahami Konsep Gaya, Apakah Pasti Miskonsepsi? Jurnal Inovasi Pendidikan Fisika dan Integrasinya, 1(2), 1-8. [Indonesian]

Tarisalia, F. S., Irawan, I. D., \& Fis, T. N. (2020). Studi Pustaka Miskonsepsi Siswa dalam Konsep Gerak Lurus, Gerak Parabola,dan Gerak Melingkar. Jurnal Kependidikan Betara (JKB), 1(4), 208-217. doi: https://doi.org/10.48109/jkb.v1i4.43 [Indonesian]

Tekege, M. (2017). Pemanfaatan Teknologi Informasi dan Komunikasi dalam Pembelajaran SMA YPPGI Nabire. JURNAL FATEKSA: Jurnal Teknologi dan Rekayasa, 2(1), 40-52. Retrieved from: https://uswim.ejournal.id/fateksa/article/view/38 [Indonesian]

Zhang, X., Wang, J., Liu, Y., Lu, G., \& Zhang, X. (2020). Kinetic Sculpture Design Using the Dynamic Cage. Journal of Physics: Conference Series, 1519, 12013. $\quad$ https://doi.org/10.1088/1742$\underline{6596 / 1519 / 1 / 012013}$ 